\title{
Late Campanian-Maastrichtian foraminifera from the Simsima Formation on the western side of the Northern Oman Mountains
}

\author{
Osman Abdelghany ${ }^{1}$ \\ Geology Department, Faculty of Science, United Arab Emirates University, Al-Ain, PO Box 17551, United Arab Emirates
}

Accepted 28 April 2003

\begin{abstract}
A precise correlation of Upper Campanian-Maastrichtian (Upper Cretaceous) sections on the western side of the Northern Oman Mountains (Jabals Qarn El Barr, El Aqabah and Malaqet in the United Arab Emirates and Jabal El Rawdah in the Sultanate of Oman), reveals two distinct facies based on microfaunal assemblages. The first indicates open marine conditions, and is represented by the Qarn El Barr section. This yields numerous planktonic foraminiferal species referable to the Globotruncana aegyptiaca (Upper Campanian), Gansserina gansseri (Upper Campanian-Middle Maastrichtian) and Abathomphalus mayaroensis (Upper Maastrichtian) planktonic foraminiferal zones. During the Campanian-Maastrichtian, this open marine environment passed laterally into shallower marine conditions that were characterized by larger foraminiferal species including Loftusia morgani, Orbitoides media, O. apiculata, Omphalocyclus macropora, Lepidorbitoides minor, Sulcoperculina dickersoni, and Siderolites calcitrapoides. This facies is well developed in the Jabal El Aqabah, Jabal El Rawdah and Jabal Malaqet sections.
\end{abstract}

(C) 2003 Elsevier Ltd. All rights reserved.

Keywords: Foraminifera; Campanian; Maastrichtian; biostratigraphy; Simsima Formation; Northern Oman Mountains

\section{Introduction}

The Late Cretaceous is one of the most significant periods in the geological history of the Arabian Peninsula, in view of the major structural and tectonic events that affected the region at this time (Glennie et al., 1974; Lippard et al., 1986; Searle \& Cox, 1999). As a result of this tectonic activity, the stratigraphic sequence records a greater complexity of facies changes than those pertaining to Early and mid-Cretaceous times (Alsharhan \& Nairn, 1990). The Upper Cretaceous rocks are widely exposed in the western foothills of the Northern Oman Mountains (Fig. 1). These rocks are the oldest units that lie unconformably upon the Semail Ophiolite and the folded, thrusted, Hawasina and Sumeini groups of Permian-Late Cretaceous age (Glennie et al., 1974; and Wilson, 2000).

The stratigraphy, facies and faunal content of the Upper Cretaceous neoautochthonous sequence of the

\footnotetext{
${ }^{1}$ Permanent address: Geology Department, Faculty of Science, Ain Shams University, PO Box 11566, Cairo, Egypt

E-mail address: Osman.Abdelghany@uaeu.ac.ae (O. Abdelghany).
}

Northern Oman Mountains have been discussed in numerous publications, including those by Glennie et al. (1974), Hamdan (1990), Alsharhan \& Kendall (1991), Anan (1993), Noweir \& Eloutefi (1997), Noweir et al. (1998), Sayed \& Mersal (1998), Boukhary et al. (1999); Alsharhan et al. (2000), Noweir \& Abdeen (2000), and Abd-Allah (2001). The present paper aims to clarify the stratigraphic setting of the Simsima Formation in the region on the basis of the foraminiferal assemblages recovered, and to discuss the facies implications of these assemblages. Four well-exposed stratigraphic sections of Campanian-Maastrichtian strata were measured and sampled (Fig. 2, Fig. 3). Three are located in the United Arab Emirates (Jabals Qarn El Barr, El Aqabah and Malaqet) and one is in the Sultanate of Oman (Jabal El Rawdah) (Fig. 1).

\section{Material}

Forty-eight rock samples were collected from the sections studied (Fig. 2, Fig. 3). Some were washed to 


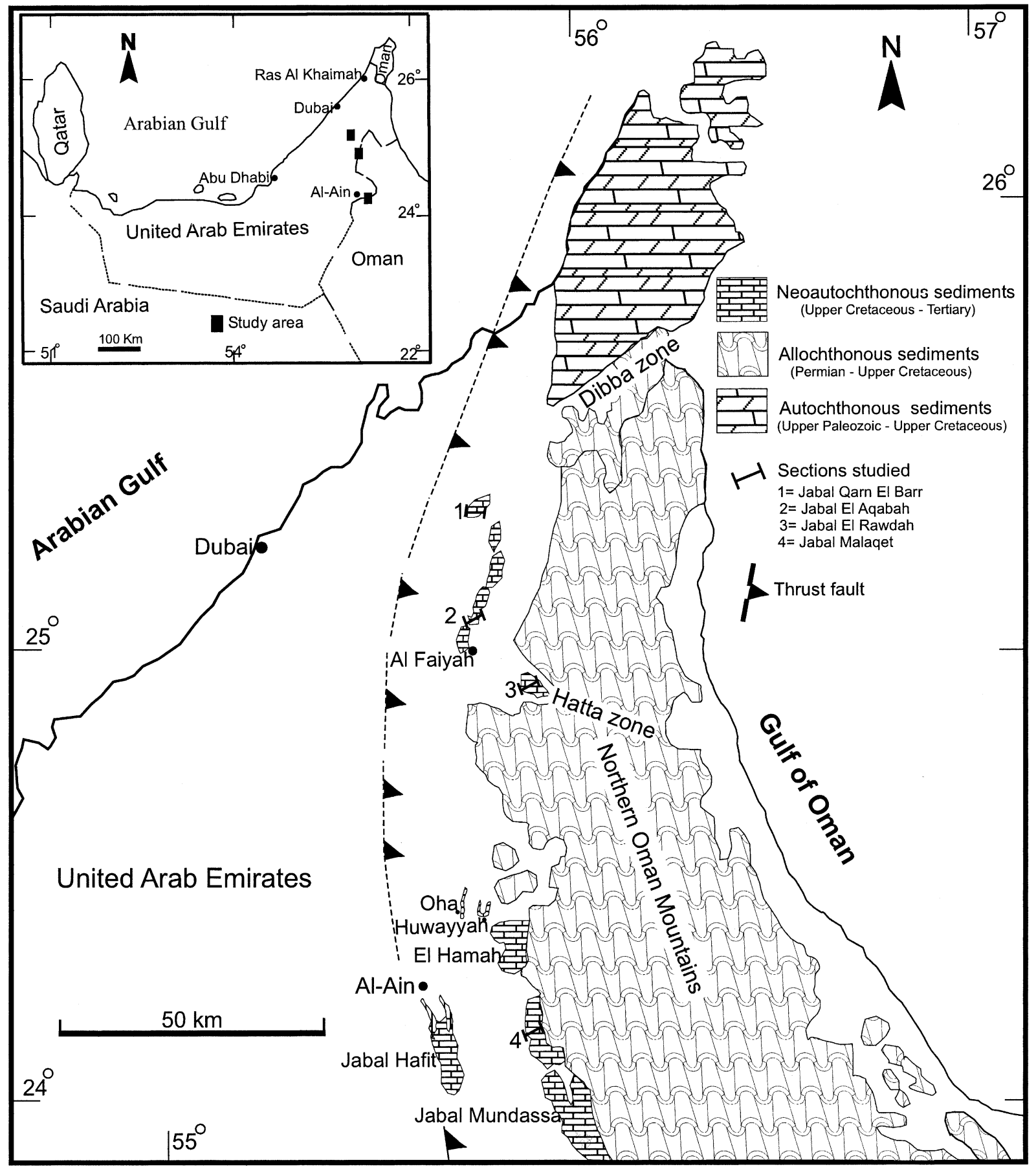

Fig. 1. Regional map for the Northern Oman Mountains showing the location of the sections studied; modified after Warrak (1996).

investigate their content of small foraminifera. Others were prepared for thin sectioning in order to study the larger foraminifera. Oriented thin sections were made of some free specimens of the latter.

\section{Stratigraphic background}

The post-obduction neoautochthonous Upper Cretaceous sedimentary succession unconformably overlies Late Cretaceous serpentinite, peridotite and pyroxenite of the Semail Ophiolite. The first marine transgression deposited shallow marine to fluviatile facies (the Qahlah Formation) over the eroded nappes of the ophiolite (Glennie et al., 1974). These were followed by shallow-water limestones, collectively referred to the Simsima Formation, now exposed at Jabals, El Aqabah, El Rawdah and Malaqet (Fig. 1). However, farther to the north at Jabal Qarn El Barr, the Simsima Formation 

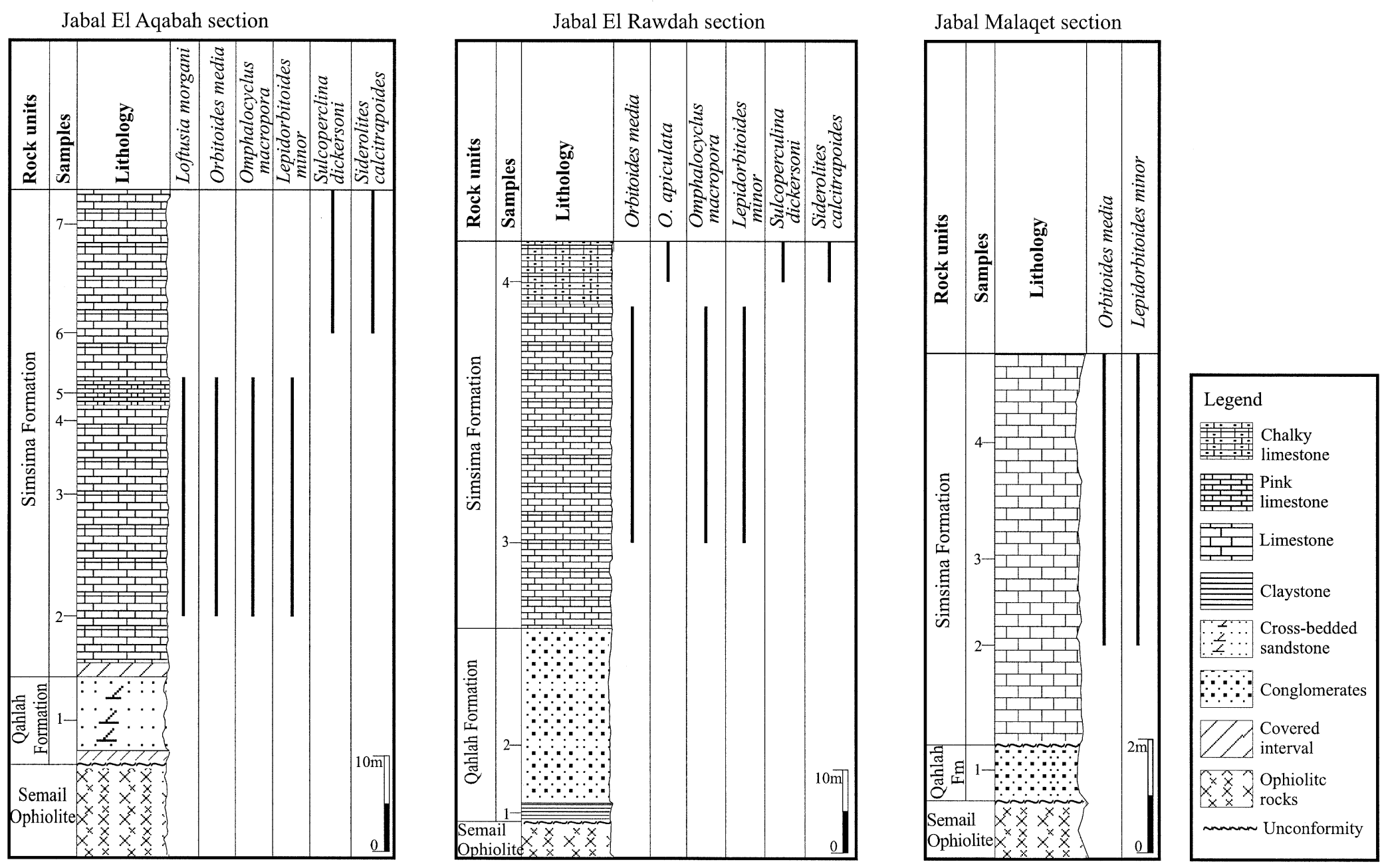

Fig. 2. Lithostratigraphic description and ranges of the larger foraminifera identified in the sections studied. 


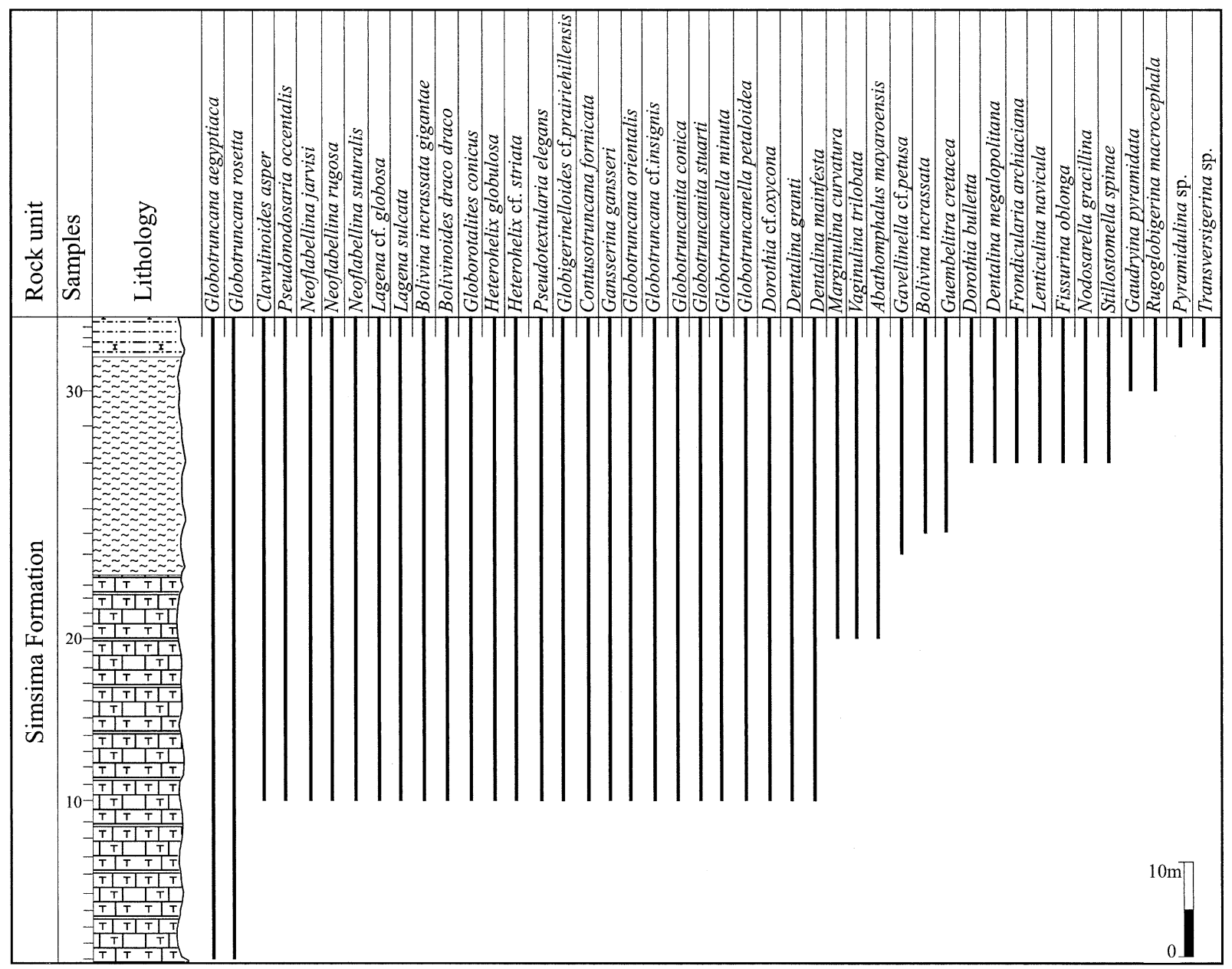

Fig. 3. Ranges of the smaller foraminifera identified from the upper Campanian-Maastrichtian rocks in the Jabal Qarn El Barr section.

is represented by deep marine pelagic deposits, as indicated by the occurrence of planktonic foraminifera. Subdivision of the stratigraphic units encountered is based on their lithostratigraphic characteristics established in the field and biostratigraphic zonation based on planktonic and benthonic larger foraminifera.

\subsection{Qahlah Formation}

The Qahlah Formation unconformably overlies the Semail Ophiolite and locally unconformably underlies the Simsima Formation (Fig. 2). It was first recorded as a formal rock unit by Glennie et al. (1974). It consists of a thick conglomerate bed containing clasts of several rock types, ranging in size from granules to boulders of variable roundness that suggest diverse source areas, both local and distant. This formation attains a thickness of $23 \mathrm{~m}$ at Jabal El Rawdah, but is only $9 \mathrm{~m}$ thick at Jabal El Aqabah, and represented by a thin conglomeratic layer $(1 \mathrm{~m})$ at the base of the Simsima Formation at Jabal Malaqet. It is missing from the Jabal Qarn El Barr section. Those thicknesses are all significantly less than that recorded at the type section near Qalhat, southeastern Oman Mountains, where the formation is about $140 \mathrm{~m}$ thick. This may be a result of the variable topography of the Semail Ophiolite on which it was deposited.

In the sections studied, the Qahlah Formation is unfossiliferous, though in the type section it is rich in rudists, corals, oysters and larger foraminifera. Glennie et al. (1974) assigned a Maastrichtian age to it based on the occurrence of Loftusia sp., and some bivalves. Hamdan (1990) dated it as Early Maastrichtian at Jabal Oha (Fig. 1), on the basis of the recovery of Globotruncana aegyptiaca Zone. Skelton et al. (1990) assigned an Early-Middle Maastrichtian age at Jabal Huwayyah (Fig. 1) based on an association of Loftusia sp., rudists and corals.

Recently, a section at Jabal Huwayyah has yielded the larger foraminiferan Pseudoorbitolina marthae (Abdelghany, in prep.). This species was first identified from the Campanian type section in France by Douvillé (1920). Its occurrence suggests a late Campanian age for the Qahlah Formation, providing support for a similar 
age assignment reported by Smith et al. (1995) from the same locality.

\subsection{Simsima Formation}

The Simsima Formation was first described by Glennie et al. (1974). Owing to the inaccessibility of the subsurface type sections, Nolan et al. (1990) designated the Jabal Al Faiyah section, on the western side of the Northern Oman Mountains (19 km northwest of Jabal El Rawdah) as an alternative surface type section for this formation. It unconformably underlies the Muthaymimah Formation, which appears to be of Paleocene to (Middle?) Eocene age (Fig. 11). Alsharhan et al. (2000) subdivided the Simsima Formation in the eastern part of the United Arab Emirates into Lower and Upper members. The Lower Member in the Qarn El Barr section (Fig. 3, Fig. 5) consists of chalky limestone with chert bands and nodules. This chalky limestone is rich in planktonic and benthonic foraminifera. This same member is $28 \mathrm{~m}$ thick at Jabal El Aqabah, $38 \mathrm{~m}$ thick at Jabal El Rawdah and $7 \mathrm{~m}$ thick at Jabal Malaqet. It consists of yellowish white, algal, orbitoidal limestone rich in macrofossils (e.g., rudists, corals and echinoids), as shown in Fig. 4.

The Upper Member in the Jabal Qarn El Barr section is $28 \mathrm{~m}$ thick and consists of marl that is also rich in planktonic and benthonic foraminifera, it is topped by calcareous siltstone. In the Jabal El Aqabah and Jabal El Rawdah sections, this member is composed of nodular, bioturbated, orbitoidal, dolomitic limestone. It attains a thickness of $23 \mathrm{~m}$ at Jabal El Aqabah and $8 \mathrm{~m}$ at Jabal El Rawdah, but is missing from the Jabal Malaqet section (Fig. 2, Fig. 5).

In the Jabal Qarn El Barr section, the late Campanian-Maastrichtian age assignment to the Simsima Formation is based on planktonic foraminifera. In the other sections (El Aqabah, El Rawdah and Malaqet), the same age determination is based on the occurrence of larger foraminifera, as discussed below.

\section{Fossils and correlation}

As noted above, the palaeontological investigation of the sections studied revealed that the Qarn El Barr section contains numerous planktonic and smaller benthonic foraminiferal species. These have enabled the subdivision of this section into three parts, namely: the Globotruncana aegyptiaca (Late Campanian), Gansserina gansseri (Late Campanian-Middle Maastrichtian) and Abathomphalus mayaroensis (Late Maastrichtian) zones. The other three sections (El Aqabah, El Rawdah and Malaqet) yielded several larger foraminiferal species (Loftusia morgani, Orbitoides apiculata, O. media,
Omphalocyclus macropora, Lepidorbitoides minor, Sulcoperculina dickersoni, and Siderolites calcitrapoides, which also support a Late Campanian-Maastrichtian age for the deposits studied. The taxonomy followed here is based on that adopted by Robaszynski et al. (1984), Caron (1985), Loeblich \& Tappan (1988), Nederbragt (1991) and Robaszynski \& Caron (1995), with special reference to the catalogue of index foraminifera by Ellis \& Messina (1967). Fifty-three foraminiferal species and subspecies were recovered. Diagnostic and/or stratigraphically important taxa are illustrated in Fig. 7, Fig. 8, Fig. 9, Fig. 10. Stratigraphic relationships between the identified planktonic and larger foraminiferal species for the sections studied are shown in (Fig. 5). A list of taxa with author attributions and year of publication are provided in the Appendix.

\subsection{Planktonic and benthonic foraminifera of the Qarn El Barr section}

The Simsima Formation in the Jabal Qarn El Barr section yielded numerous planktonic foraminiferal species, especially those belonging to genera Heterohelix and Globotruncana. In addition, several benthonic species were also encountered, some of which contribute to the age determination, as noted above. The distribution of the identified planktonic and small benthonic foraminiferal species is shown in (Fig. 3).

\subsection{Globotruncana aegyptiaca Interval Zone (Late Campanian)}

This zone includes only the basal part $(18 \mathrm{~m})$ of the Simsima Formation in the Qarn El Barr section. Its lower boundary is indicated by the first occurrence of Globotruncana aegyptiaca, at the top of the first quarter of chron 32 (Fig. 6), while its upper boundary is indicated by the first appearance of Gansserina gansseri. The associated species in this zone is Globotruncana rosetta.

The Globotruncana aegyptiaca interval zone is identified here for the first time; previously only the Gansserina gansseri interval zone (Middle Maastrichtian) was recognized (Hamdan, 1990). These data support a Late Campanian age for the basal part of the Simsima Formation in the Qarn El Barr section.

\subsection{Gansserina gansseri Interval Zone (Late Campanian-Middle Maastrichtian)}

This zone encompasses the middle part of the Simsima Formation and is $17 \mathrm{~m}$ thick in the Qarn El Barr section. The lower boundary of the zone is indicated by the first appearance of Gansserina gansseri, in the highest part of chron 32 (Fig. 6), while its upper 

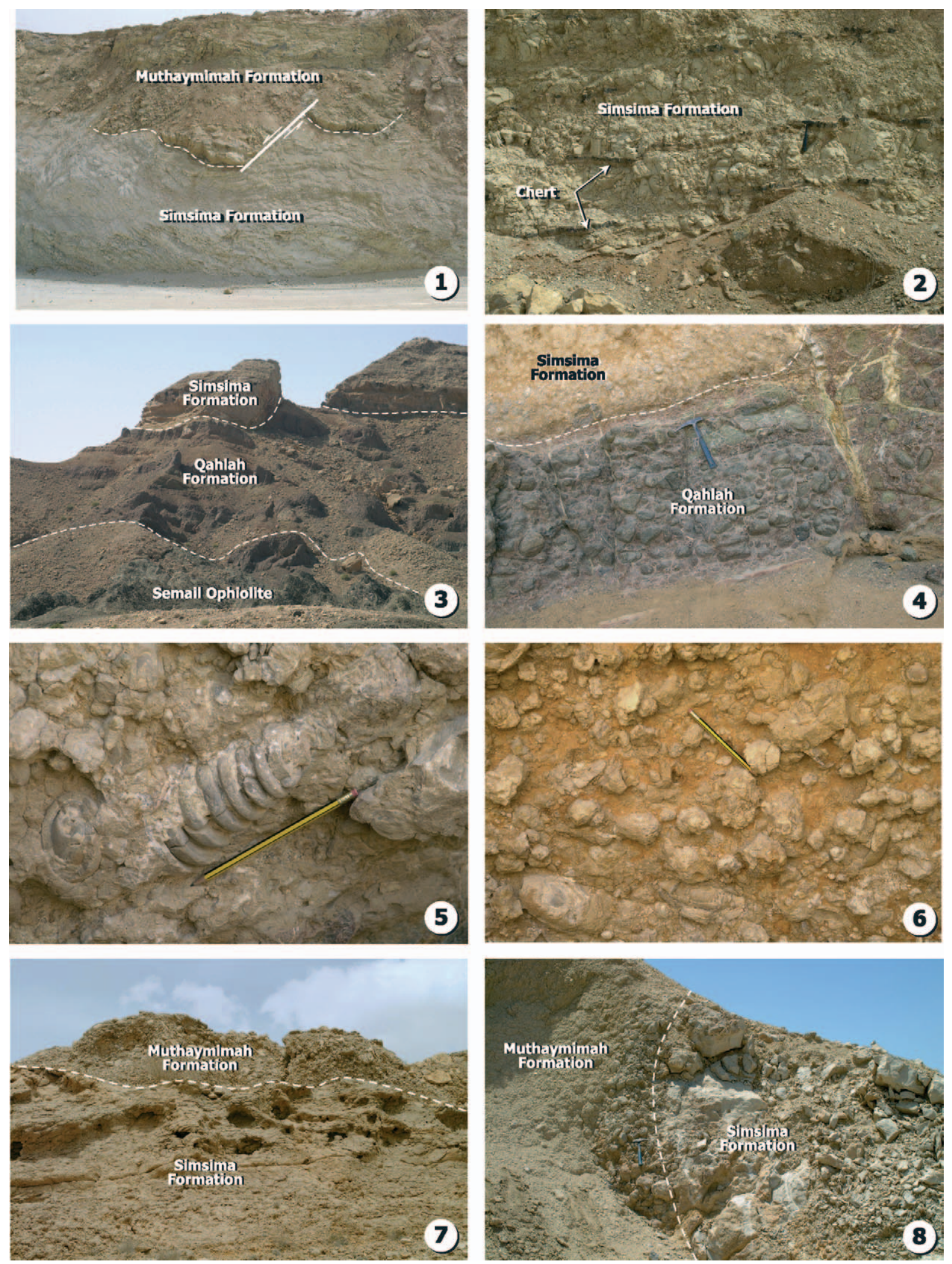

Fig. 4. 1-8, field photographs showing the stratigraphic relations and the characteristic fossils of the Simsima Formation in the sections studied. 1, 2, Jabal Qarn El Barr section. 3, 4, Al-Faiyah section. 5, 6, showing characteristic fossils (Orbitoides, calcareous red algae and mollusc shell fragments) at the Al-Faiyah locality. 7, Jabal El Rawdah section. 8, Jabal Malaqet section. 


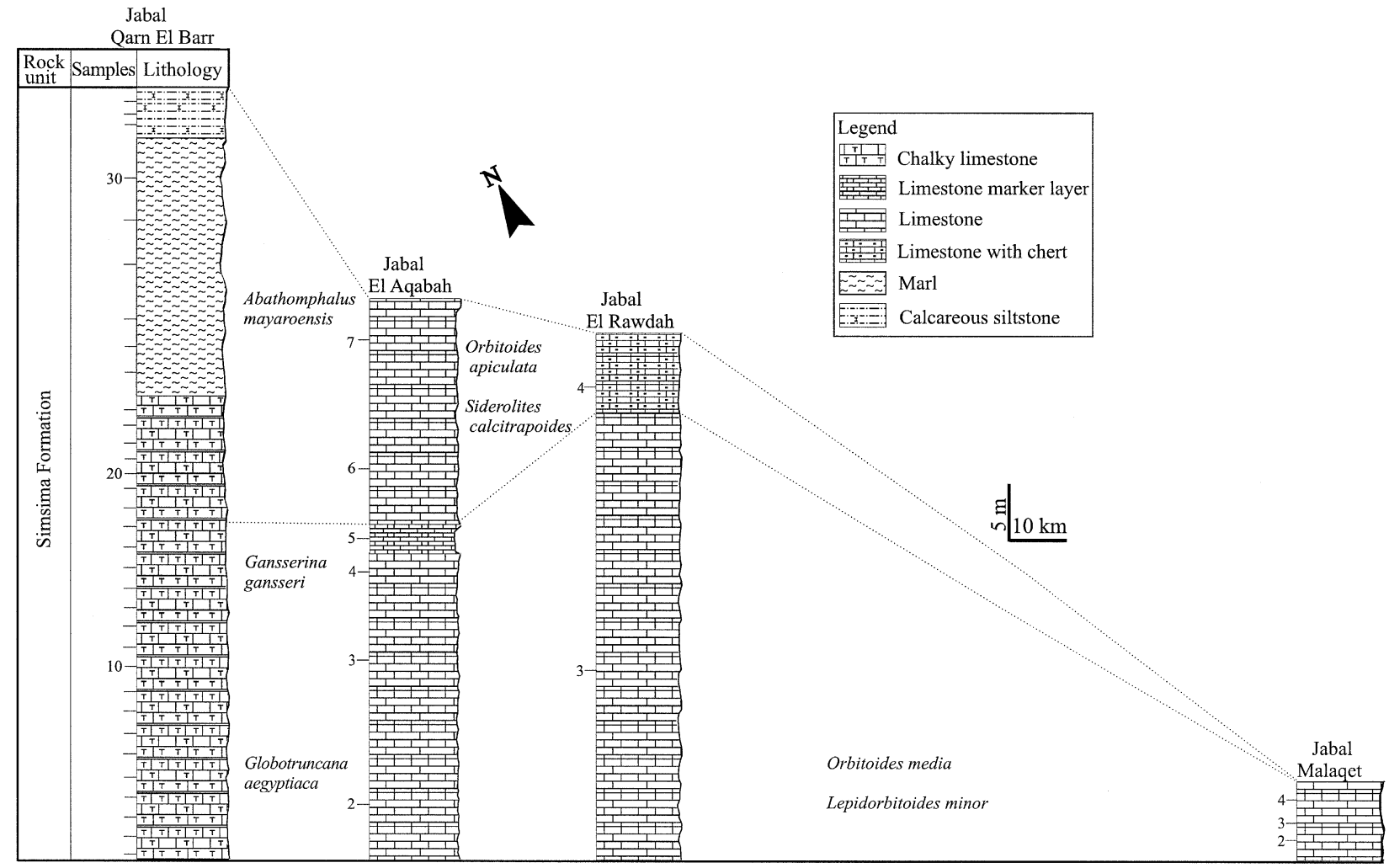

Fig. 5. Correlation of the sections studied based on the biozones identified in the Simsima Formation.

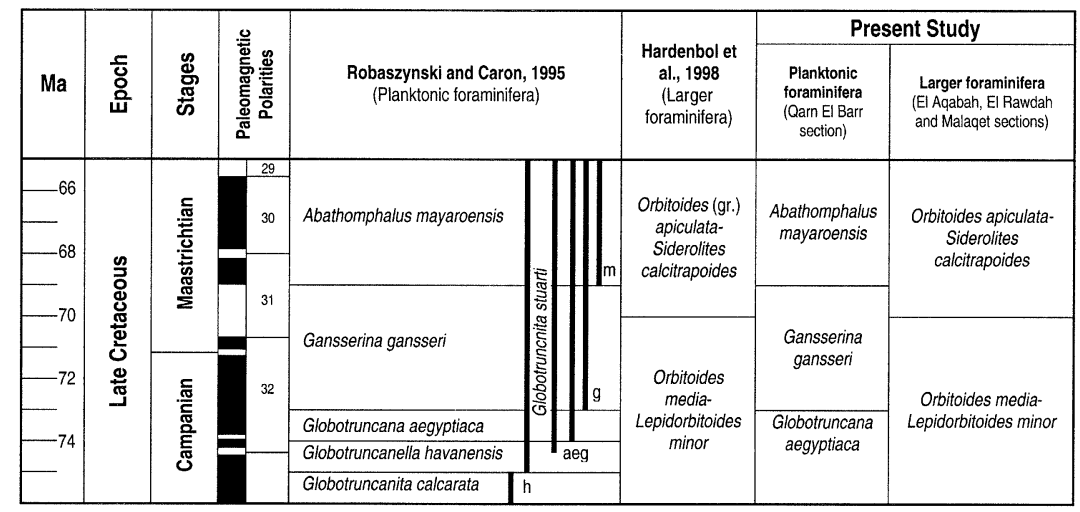

Fig. 6. Comparison of zones and assemblages between the planktonic and larger foraminifera according to different authors (time-scale and stages after Gradstein et al., 1994; palaeomagnetic polarities after Gradstein et al., 1994, and Premoli Silva \& Sliter, 1994).

boundary is indicated by the first appearance of Abathomphalus mayaroensis. The associated species include Bolivinoides draco draco, Heterohelix globulosa, $H$. cf. striata, Pseudotextularia elegans, Globigerinelloides cf. prairiehillensis, Contusotruncana fornicata, Globotruncana orientalis, G. cf. insignis, Globotruncanita conica, G. stuarti, Globotruncanella minuta and G. petaloidea.

\subsection{Abathomphalus mayaroensis partial Range Zone (Late Maastrichtian)}

This zone occupies the uppermost $34 \mathrm{~m}$ of the Simsima Formation in the Qarn El Barr section. The lower boundary is indicated by the first appearance of Abathomphalus mayaroensis, at the base of chron 31 (Fig. 6), while the upper boundary is placed at the last 


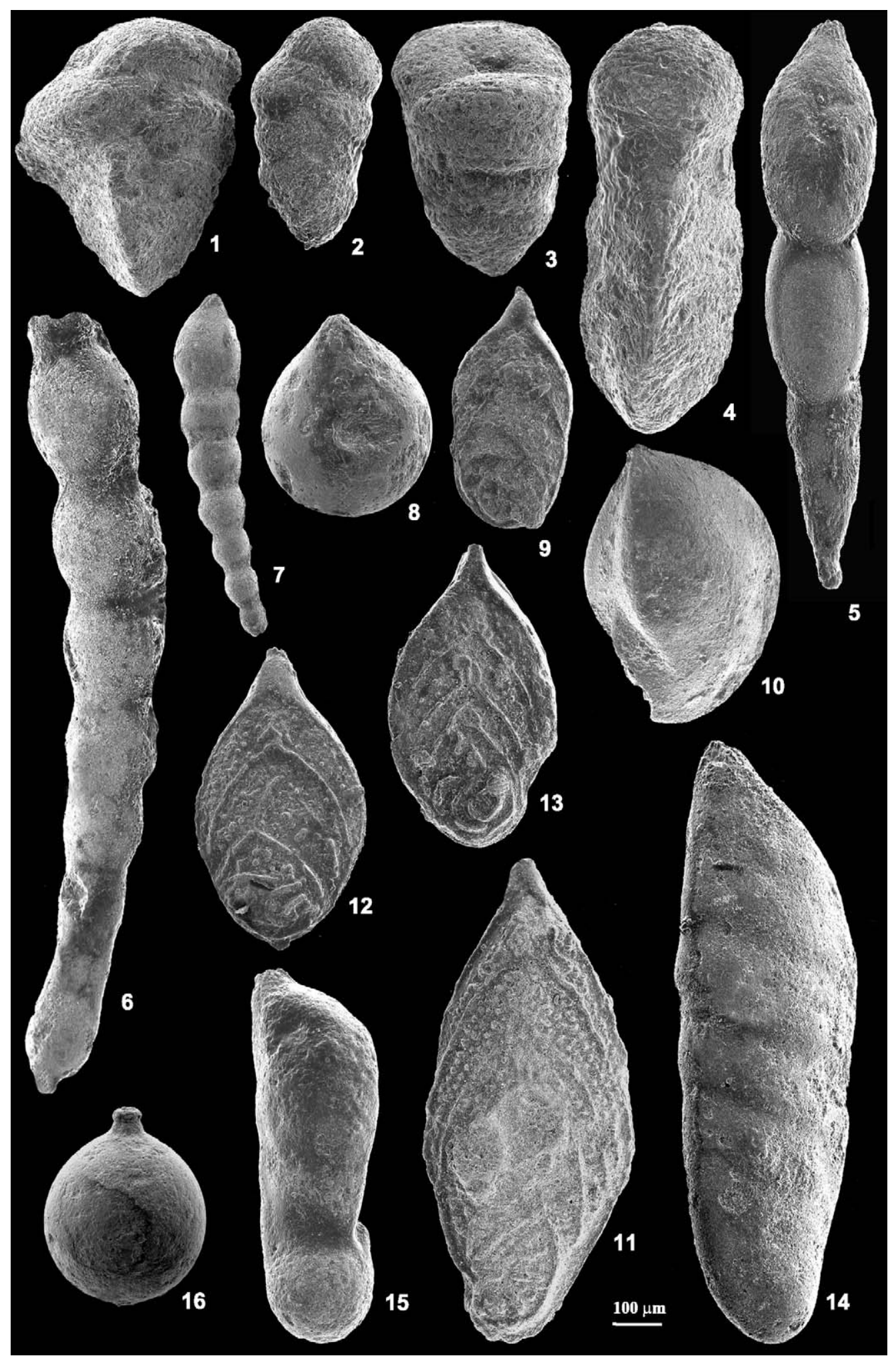

Fig. 7. Scale bar represents $100 \mu \mathrm{m}$. All the specimens were recovered from the Simsima Formation, Jabal Qarn El Barr section; for author attributions and year of publication, see Appendix. 1, Gaudryina pyramidata, sample 30. 2, Dorothia bulletta, sample 28. 3, Dorothia cf. oxycona, sample 28. 4, Clavulinoides asper, sample 10. 5, Dentalina mainfesta, sample 28. 6, Dentalina megalopolitana, sample 28. 7, Dentalina granti, sample 28. 8, Pseudonodosaria occentalis, sample 10. 9, Frondicularia archiaciana, sample 28. 10, Lenticulina navicula, sample 28. 11, Neoflabellina jarvisi, sample 10. 12, Neoflabellina rugosa, sample 10,13, Neoflabellina suturalis, sample 10. 14, Marginulina curvatura, sample 20. 15, Vaginulina trilobata, sample 20. 16, Lagena cf. globosa, sample 10. 


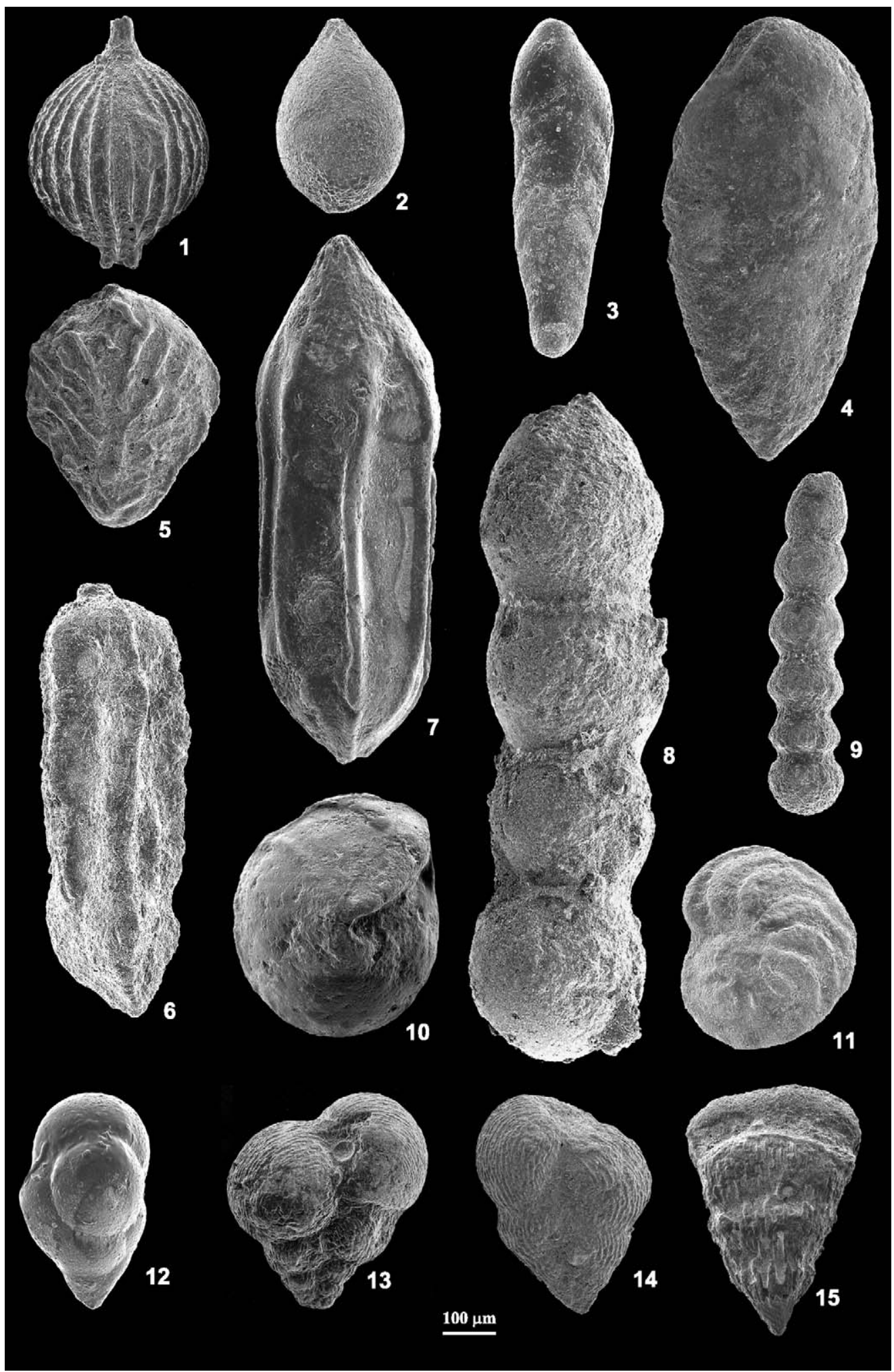

Fig. 8. Scale bar represents $100 \mu \mathrm{m}$. All the specimens were recovered from the Simsima Formation, Jabal Qarn El Barr section; for author attributions and year of publication, see Appendix. 1, Lagena sulcata, sample 10. 2, Fissurina oblonga, sample 28. 3, Bolivina incrassata, sample 26. 4, Bolivina incrassata gigantae, sample 10. 5, Bolivinoides draco draco, sample 10. 6, Transversigerina sp., sample 31. 7, Pyramidulina sp., sample 31. 8, Nodosarella gracillina, sample 28. 9, Stillostomella spinae, sample 28. 10, Globorotalites conicus, umbilical side, sample 10. 11, Gavellinella cf. petusa, umbilical side, sample 25. 12, Guembelitra cretacea, sample 26. 13, Heterohelix globulosa, sample 10. 14, Heterohelix cf. striata, sample 10. 15, Pseudotextularia elegans, sample 10. 


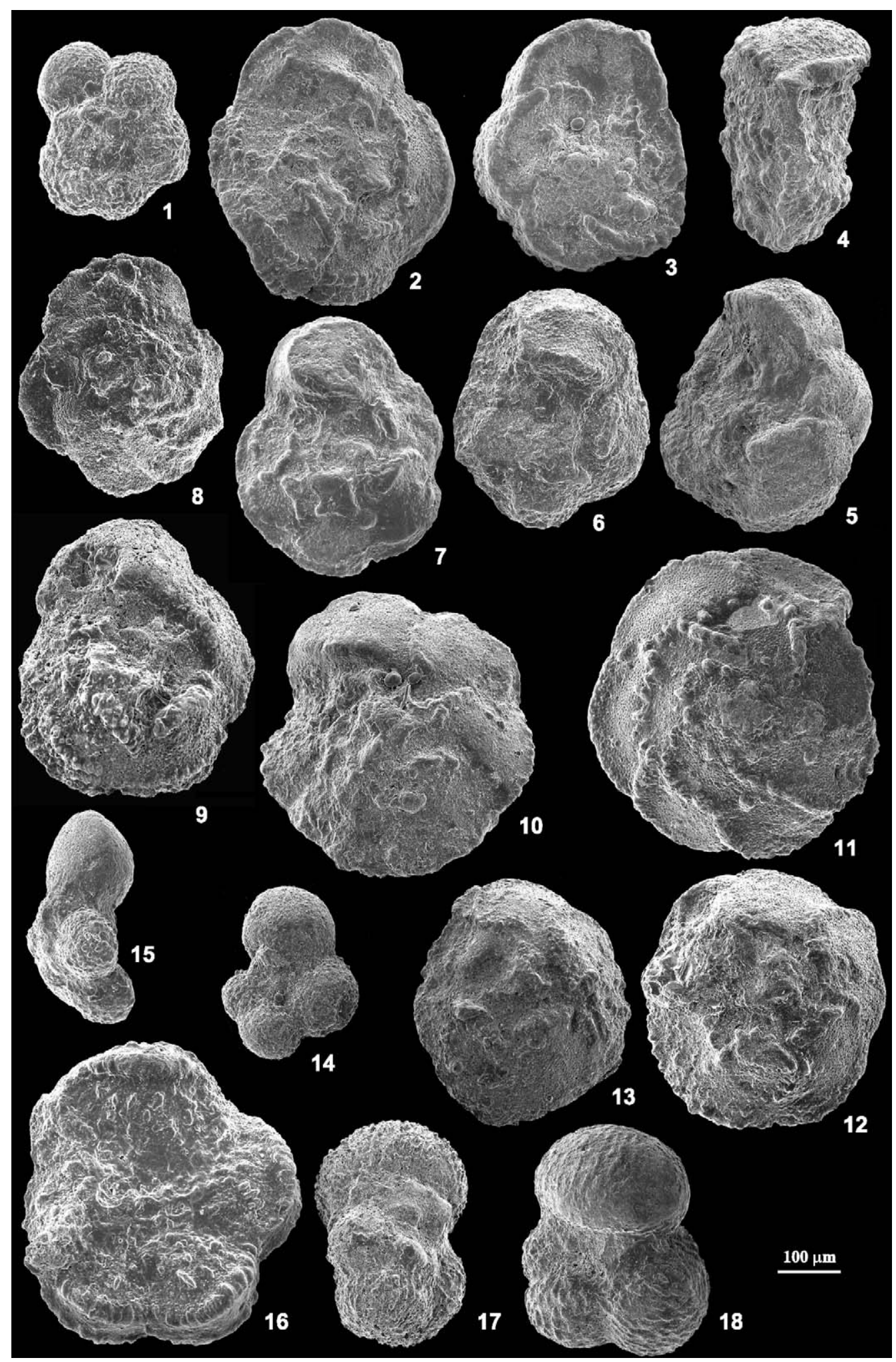

Fig. 9. Scale bar represents $100 \mu \mathrm{m}$. All the specimens were recovered from the Simsima Formation, Jabal Qarn El Barr section, sample 10 except where stated; for author attributions and year of publication, see Appendix. 1, Globigerinelloides cf. prairiehillensis, ventral side. 2, Contusotruncana fornicata, spiral side. 3-5, Gansserina gansseri, 3, spiral side; 4, side view; 5, umbilical side. 6, Globotruncana aegyptiaca, umbilical side. 7, Globotruncana orientalis, umbilical side. 8, 9, Globotruncana rosetta, 8, spiral side; 9, umbilical side, sample 1. 10, Globotruncana cf. insignis, umbilical side. 11, Globtruncanita conica, spiral side. 12, 13, Globotruncanita stuarti, umbilical sides. 14, Globotruncanella minuta, umbilical side. 15, Globotruncanella petaloidea, side view. 16, Abathomphalus mayaroensis, umbilical side, sample 20. 17, 18, Rugoglobigerina macrocephala, 17, side view; 18, umbilical view, sample 30 . 

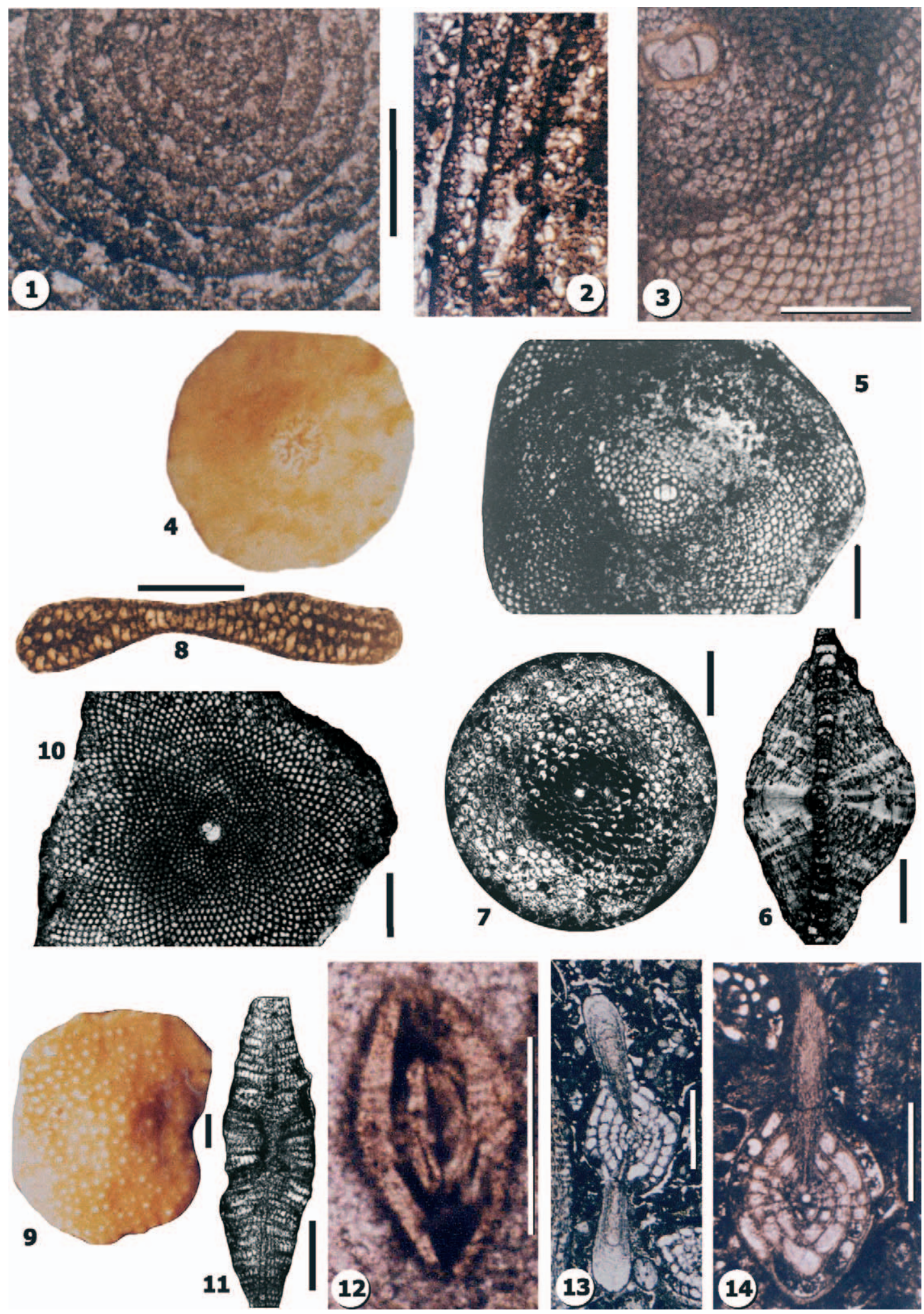

Fig. 10. Scale bars represent $1 \mathrm{~mm}$. All the specimens were recovered from the Simsima Formation; for author attributions and year of publication, see Appendix. 1, 2, Loftusia morgani; 1, equatorial section; 2, axial section, Jabal El Aqabah section, samples 1 and 2 respectively. 3 , Orbitoides apiculata, equatorial section, Jabal El Rawdah section, sample 4. 4-6, Orbitoides media, 4, external view; 5, equatorial section; 6, axial section, Jabal El Rawdah section, sample 4. 7, 8, Omphalocyclus macropora, 7, equatorial section; 8 axial section, Jabal El Aqabah section, sample 2. 9-11, Lepidorbitoides minor, 9, external view; 10, equatorial section; 11, axial section, Jabal El Rawdah section, sample 3. 12, Sulcoperculina dickersoni, axial section, Jabal El Aqabah section, sample 6.13, 14, Siderolites calcitrapoides, equatorial section, Jabal El Rawdah section, sample 4. 


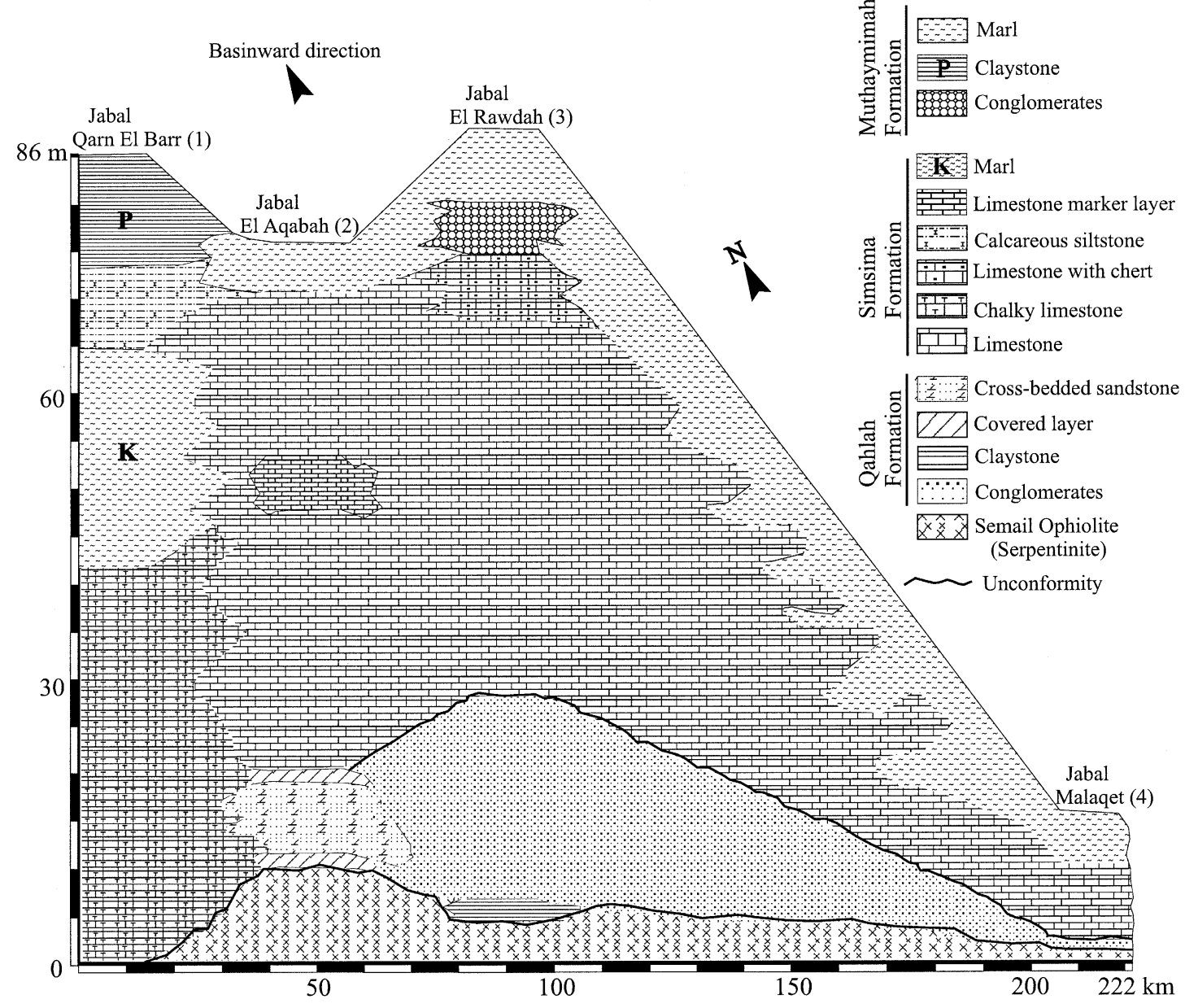

Fig. 11. Stratigraphic cross-section showing facies distribution in the sections studied.

occurrence of globotruncanids; e.g. G. aegyptiaca and G. havanensis. The associated species include Guembelitria cretacea, Heterohelix globulosa, $H$. cf. striata and Rugoglobigerina macrocephala. Hamdan (1990) identified this zone only in the upper $13 \mathrm{~m}$ of the pelagic marls and calcareous shales in the Qarn El Barr section.

\subsection{Larger benthonic foraminifera}

Publications dealing with larger Cretaceous foraminifera of the United Arab Emirates are relatively few, despite there being many exposures that yield them. Kureshy (1980) noted that the isolation of Cretaceous larger foraminiferal assemblages in different parts of the world during the Cretaceous Period meant that they evolved independently in different areas and that their distribution was controlled by ecological factors. Cox (1937) and Al-Omari \& Sadek (1976) documented loftusiids together with Omphalocyclus macroporous and Orbitoides apiculata in both Oman and Iraq. Meriç et al. (2001) discussed the palaeogeography of the Loftusia species based on a model for the plate tectonic history of Turkey and areas further afield in the Tethyan Realm. Loftusia morgani was recorded by these authors as well as by Cox (1937) and Al-Omari \& Sadek (1976) from Upper Maastrichtian deposits in Turkey, Iran and Iraq, respectively.

Several species of larger foraminifera have been encountered in the shallow carbonate facies of the Simsima Formation. These include Loftusia morgani in the Jabal El Aqabah section; Orbitoides apiculata in the Jabal El Rawdah section; Omphalocyclus macropora, Sulcoperculina dickersoni and Siderolites calcitrapoides in both the Jabal El Aqabah and Jabal El Rawdah sections; and Orbitoides media and Lepidorbitoides minor in the Jabal El Aqabah, Jabal El Rawdah and Jabal Malaqet sections. This fauna allows the subdivision of the Simsima Formation into two distinct orbitoidal units: a lower horizon yielding Orbitoides media and Lepidorbitoides minor and an upper one yielding Orbitoides apiculata and Siderolites calcitrapoides. The lower horizon can be correlated with the Globotruncana 
aegyptiaca and lower part of the Gansserina gansseri interval zones (Fig. 5, Fig. 6), whereas the upper horizon can be correlated with the upper part of the Gansserina gansseri Interval Zone and the Abathomphalus mayaroensis Zone (Fig. 5, Fig. 6).

Larger foraminifera are absent from the deeper water facies in the Qarn El-Barr section. Near the base of the Simsima Formation in shallow-water facies a specimen of Loftusia morgani was recovered with ophiolite particles within its agglutinated test. These particles were probably derived from the underlying ophiolite-derived, shallow-water clastics of the Qahlah Formation. A similar conclusion was reached by Meriç et al. (2001), who found Middle-Upper Maastrichtian Loftusia species in Turkey with tiny ophiolitic rock particles adhering to their tests. They concluded that the shallow-water ophiolite platforms formed during Late Maastrichtian tectonic movements, which culminated in the closure of the Tethyan Ocean. The distribution of facies in the sections discussed herein indicates that the Late Cretaceous sea in the region deepened towards the NNW, i.e. towards the Qarn El Barr section (Fig. 5, Fig. 11).

\section{Conclusions}

Detailed studies of the diverse assemblages of late Campanian-Maastrichtian planktonic and larger foraminifera recovered from the sections studied have enabled biostratigraphic and palaeoenvironmental conclusions to be drawn. The Qarn El Barr section has been referred to three biozones: the Globotruncana aegyptiaca (Upper Campanian), Gansserina gansseri (Upper Campanian-Middle Maastrichtian) and Abathomphalus mayaroensis (Upper Maastrichtian) zones. Two associations of larger foraminifera, Orbitoides mediaLepidorbitoides minor and Orbitoides apiculataSiderolites calcitrapoides, have been recognized in the other sections examined. A correlation between the open marine facies containing planktonic foraminifera with the shallow marine facies yielding larger foraminifera has also been attempted. Hence, the Jabal Qarn El Barr section has been correlated with sections at Jabals El Aqabah, El Rawdah and Jabal Malaqet in the United Arab Emirates and Sultanate of Oman.

\section{Acknowledgements}

I acknowledge with deep appreciation the assistance and support given by Prof. Dr Mohamed Boukhary and Prof. Dr Ahmed Aly Ismail, Ain Shams University, Cairo, Egypt, and for their critical reading of the original version of the manuscript and review of the identifications of the fauna studied. I am greatly indebted to Dr Thomas Fowler, UAE University for critically reading and improving the English language, and Dr Ashraf Baghdady, of the same university for his valuable comments and fruitful discussions. The penetrating critical comments by anonymous reviewers and Prof. Dr David J. Batten have greatly improved the manuscript and are much appreciated. I thank the UAE University for providing the necessary facilities for completing this work.

\section{Appendix A. Smaller foraminifera recorded from the Jabal Qarn El Barr section}

Order: Foraminiferida Eichwald, 1830

Abathomphalus mayaroensis (Bolli, 1951), Fig. 9.16.

Bolivina incrassata Reuss, 1851; Fig. 8.3.

Bolivina incrassata gigantae Wicher, 1949; Fig. 8.4.

Bolivinoides draco draco (Marsson, 1878); Fig. 8.5.

Clavulinoides asper (Cushman, 1926); Fig. 7.4.

Contusotruncana fornicata (Plummer, 1931); Fig. 9.2.

Dentalina granti (Plummer, 1927); Fig. 7.7.

Dentalina mainfesta (d'Orbigny, 1840); Fig. 7.5.

Dentalina megalopolitana (Reuss, 1855); Fig. 7.6.

Dorothia bulletta (Carsey, 1926); Fig. 7.2.

Dorothia cf. oxycona (Reuss, 1860); Fig. 7.3.

Fissurina oblonga Reuss, 1863; Fig. 8.2.

Frondicularia archiaciana (d'Orbigny, 1840); Fig. 7.9.

Gansserina gansseri (Bolli, 1951); Fig. 9. 3-5.

Gaudryina pyramidata (Cushman, 1926); Fig. 7.1.

Gavellinella cf. petusa (Marsson, 1942); Fig. 8.11.

Globigerinelloides ef. prairiehillensis; Fig. 9.1.

Globorotalites conicus (Carsey, 1926); Fig. 8.10.

Globotruncana aegyptiaca Nakkady, 1950; Fig. 9.6.

Globotruncana cf. insignis Gandolfi, 1955, Fig. 9.10.

Globotruncana orientalis El Naggar, 1966, Fig. 9.7.

Globotruncana rosetta Carsey, 1926, Fig. 9.8, 9.

Globotruncanella minuta Robaszynski, Caron,

Gonzalez \& Wonders, 1984, Fig. 9.14.

Globotruncanella petaloidea (Gandolfi, 1955), Fig. 9.15 .

Globtruncanita conica (White, 1928), Fig. 9.11.

Globotruncanita stuarti (de Lapparent, 1918), Fig.

9.12, 13 .

Guembelitria cretacea Cushman, 1933; Fig. 8.12.

Heterohelix globulosa Ehrenberg, 1840; Fig. 8.13.

Heterohelix cf. striata Ehrenberg, 1840; Fig. 8.14.

Lagena cf. globosa Montagu, 1803; Fig. 7.16.

Lagena sulcata Walker \& Jacob, 1798; Fig. 8.1.

Lenticulina navicula (d'Orbigny, 1840); Fig. 7.10.

Marginulina curvatura Cushman, 1938; Fig. 7.14.

Neoflabellina jarvisi (Cushman, 1935); Fig. 7.11.

Neoflabellina rugosa (d'Orbigny, 1840); Fig. 7.12.

Neoflabellina suturalis (Cushman, 1935); Fig. 7.13.

Nodosarella gracillima Cushman, 1946; Fig. 8.8. 


\section{8.}

Pseudonodosaria occidentalis (Cushman, 1923); Fig.

Pseudotexturalia elegans (Rzehak, 1891); Fig. 8.15.

Pyramidulina sp.; Fig. 8.7.

Rugoglobigerina macrocephala Brönnimann, 1952,

Fig. 9.17, 18.

Stilostmella spinae (Cushman, 1939); Fig. 8.9.

Transversigerina sp.; Fig. 8.6.

Vaginulina trilobata (d'Orbigny, 1840); Fig. 7.15.

\section{Appendix B. Larger foraminifera recorded from the Jabal El Aqabah, El Rawdah section and Malaqet sections}

Lepidorbitoides minor (Schlumberger, 1902); Fig. 10.9-11.

Loftusia morgani Douvillé, 1904; Fig. 10.1, 2.

Omphalocyclus macropora (Lamarck, 1816); Fig.

$10.7,8$.

Orbitoides apiculata Schlumberger, 1902; Fig. 10.3.

Orbitoides media (d'Archiac, 1837); Fig. 10.4-6.

Siderolites calcitrapoides Lamarck, 1801; Fig. 10.13, 14.

Sulcoperculina dickersoni (Palmer, 1934); Fig. 10.12.

\section{References}

Abd-Allah, A.M.A., 2001. Folding and faulting of neoautochthonous sequence in the Al Faiyah fold belt: Northern Oman Mountains, United Arab Emirates. Ann. Geol. Surv. Egypt 24, 413-433.

Al-Omari, F.S., Sadek, A., 1976. Loftusia from northern Iraq. Rev. Española Micropaleontol. 8, 57-67.

Alsharhan, A.S., Kendall, C.G., 1991. Cretaceous chronostratigraphy, unconformities and eustatic sea-level changes in the sediments of Abu Dhabi, United Arab Emirates. Cret. Res. 12, 379-401.

Alsharhan, A.S., Nairn, A.E.M., 1990. A review of the Cretaceous formations in the Arabian Peninsula and Gulf: Part III. Upper Cretaceous (Aruma Group) stratigraphy and paleogeography. J. Petrol. Geol. 13, 247-266.

Alsharhan, A.S., Zico, A., Shebl, H.T., Whittle, G.L., 2000. Microfacies and microfabrics of Maastrichtian carbonates, northwestern Oman Mountains, U.A.E. SEPM (Soc. Sed. Geol.) Spec. Publ. 69, 129-142.

Anan, H.S., 1993. Maastrichtian-Paleocene micropaleontology, biostratigraphy of Qarn El Barr section, Al Dhayd area, United Arab Emirates. Al Azhar Bull. Sci. 4, 639-670.

Boukhary, M.A., Carter, B.D., Alsharhan, A.S., et al., 1999. Maastrichtian echinoids from the Simsima Formation, northwestern Oman mountains, UAE: asystematic view and ecological implications. Rev. Paléobiol. Genève 18, 577-595.

Caron, M., 1985. Cretaceous planktic foraminifera. In: Bolli, H.M., Saunders, J.B., Perch-Nielsen, K. (Eds.). Plankton Stratigraphy. Cambridge University Press, Cambridge, pp. 17-86.

Cox, F.T., 1937. The genus Loftusia in southwestern Iran. Eclogae Geol. Helv. 30, 431-450.

Douvillé, H., 1920. Revision des Orbitoides du Crétacé; les Omphalocyclus. Comptes Rendu Séances, Soc. Géol. France, 166-167.
Ellis, B.F., Messina, A.R., 1967. Catalogue of index foraminifera, volume 3. The American Museum of Natural History, Special Publication, New York.

Glennie, K.W., Boeuf, M.G.A., Hughes Clarke, M.W., et al., 1974. Geology of the Oman Mountains. Verhandelingen van Ket Koninklijk. Nederlands Geologisch-Minjbouwkundig Genootschap (Trans. Roy.Dutch Geol. Mineral. Soc.) 31, 423 pp.

Gradstein, F.M., Agterberg, F.P., Ogg, J.G., et al., 1994. A Mesozoic time scale. J. Geophys. Res 99, 24,051-24,074.

Hamdan, A.A., 1990. Maastrichtian globotruncanids from the western front of the Northern Oman Mountains: implications for the age of post-orogenic strata. J. Fac. Sci. United Arab Emirates Univ. 2, 53-66.

Hardenbol, J., Thierry, J., Farley, M.B., et al., 1998. Mesozoic and cenozoic sequence chronostratigraphic framework of European basins. In: de Graciansky, P.Ch., Hardenbol, J., Jacquin, Th. et al., (Eds.). Mesozoic and Cenozoic Sequence Stratigraphy of European Basins. SEPM (Society for Sedimentary Geology) Special Publication Series, 60.

Kureshy, A.A., 1980. Paleobiogeography of Cretaceous larger foraminifera of Pakistan and the Caribean region and their bearing on continental drift. Cret. Res. 1, 93-100.

Lippard, S.J., Shelton, A.W., Gass, I.G., 1986. The Ophiolite of Northern Oman. Geol. Soc. London Mem. 11, 178 pp.

Loeblich, A.R., Tappan, H., 1988. Foraminiferal genera and their classification, 1. Van Nostrand Reinhold International Company, New York970 pp., vol. 2, viii +847 plates.

Meriç, E., Ersoy, S., Görmüs, M., 2001. Palaeogeographical distribution of the species of Loftusia (Foraminiferida) in the Tethyan Ocean during the Maastrichtian (Late Cretaceous). Cret. Res. 22, 353-364.

Nederbragt, A.J., 1991. Late Cretaceous biostratigraphy and development of Heterohelicidae (planktic foraminifera). Micropaleontology 37, 329-372.

Nolan, S.C., Skelton, P.W., Clissold, B.P., et al., 1990. Maastrichtian to early Tertiary stratigraphy and palaeogeography of the Central and Northern Oman Mountains. In: Robertson, A.H.F., Searle, M.P., Ries, A.C. (Eds.). The Geology and Tectonics of the Oman Region. Geological Society of London, Special Publication, 49, pp. 495-519.

Noweir, M.A., Eloutefi, N.S., 1997. The structure and stratigraphy of Jabal Malaqet-Jabal Mundassa area, southeast Al-Ain, Northern Oman Mountains, United Arab Emirates. Neues Jahr. Geol. Paläont. Abhandl. 204, 263-284.

Noweir, M.A., Alsharhan, A.S., Boukhary, M.A., 1998. Structural setting and stratigraphic evolution of the northwestern Oman Mountain Front, United Arab Emirates. GeoArabia 3, 387-398.

Noweir, M.A., Abdeen, M.M., 2000. Structural evolution of Jabal Rawdah area, Hatta Zone, northwestern Oman Mountains front. Egyptian J. Geol. 44, 219-235.

Premoli Silva, I., Sliter, W.V., 1994. Cretaceous planktonic foraminiferal biostratigraphy and evolutionary trends from the Bottacione section, Gubbio, Italy. Paleontol. Italica $82,89 \mathrm{pp}$.

Robaszynski, F., Caron, M., 1995. Foraminiféres planctoniques du Crétacé: commentaire de la zonation Europe-Méditerranée. Bull Soc. Geol. France 166, 681-692.

Robasznski, R, Caron, M., González Donoso, J.M., et al., 1984. Atlas of Late Cretaceous globotruncanids. Rev. Micropaleontol. 26, $145-305$.

Sayed, M.G., Mersal, M.A., 1998. Surface geology of Jebel Rawdah, Oman Mountains. GeoArabia 3, 401-414.

Searle, M.P., Cox, J., 1999. Tectonic setting, origin and obduction of the Oman ophiolite. Geol. Soc. America Bull. 111, 104-122.

Skelton, P.W., Nolan, S.C., Scott, R.W., 1990. The Maastrichtian transgression onto the northwestern flank of the Proto-Oman Mountains: sequences of rudist-bearing beach to open shelf facies. In: Robertson, A.H.F., Searle, M.P., Ries, A.C. (Eds.). The 
Geology and Tectonics of the Oman Region. Geological Society of London Special Publication, 49, pp. 521-547.

Smith, A.B., Morris, N.J., Kennedy, W.J., et al., 1995. Late Cretaceous carbonate platform faunas of the United Arab Emirates-Oman border region. Bull. Nat. Hist. Mus. London (Geol.) 51, 91-119.
Warrak, M.A., 1996. Origin of the Hafit structure: implications for timing the Tertiary deformation in the Northern Oman Mountains. J. Struc. Geol. 18, 803-818.

Wilson, H.H., 2000. The age of the Hawasina and other problems of Oman Mountain geology. J. Petrol. Geol. 23, 345-362. 